\title{
Testing the Moderating Role of Social Context on Media Violence Effect in the Case of Peer Aggression among Adolescents
}

\author{
Tena Velki, Gordana Kuterovac Jagodić \\ University of J. J. Strossmayer
}

\begin{abstract}
The main aim of the study was to examine a potential moderator role of social context in which children are exposed to media (alone, with peers, with parents) in the relationship between the frequency of media use and the frequency of committed peer aggression. The study included 880 elementary school students, which completed the following self-assessment measures: Peer violence among school children questionnaire (Velki, Kuterovac Jagodić, \& Vrdoljak, 2012), and Exposure to the media scale (Velki \& Kuterovac Jagodić, 2012). A moderation effect of parental and peer social context was found; e.g., social context had a positive effect on decreasing the correlation between watching TV and electronic peer aggression. Peers social context during playing computer games was associated with decrease in physical peer aggression. Browsing the Internet with parents or peers also decreased physical and/or electronic peer aggression. The importance of social context as a protective factor is highlighted in the discussion.
\end{abstract}

Key words: electronic media, peer aggression, social context, parents, peers

\section{Introduction}

Many of the research studies conducted during the last fifty years suggest that exposure to media can both positively and negatively influence child and adolescent development, particularly the social and emotional aspects (e.g., Wilson, 2008). However, the unfavorable effects of media have raised more public concerns, particularly in recent times, when increased affordability and availability of fixed and mobile media platforms have resulted in the possibility of media exposure 24 hours a day. Violence is the most researched negative media content. Analyses of TV programs reveal that

Correspondence regarding this article address to Tena Velki, Faculty of Education, University of J. J. Strossmayer of Osijek, Osijek, Croatia. Email: tena.velki@gmail.com

Received December 14, 2015 by 18 years of age an average American young person will have viewed 200000 acts of violence on television (Huston et al., 1992) and most of them in children's TV programs (Wilson et al., 2002). The content analysis of Croatian public and commercial television stations indicated that Croatian children are also exposed to significant amount of TV violence (Wertag, Šakić, Boban, \& Bakić-Tomić, 2006). In addition to TV programs children and youth are also exposed to potentially unsafe contents, particularly violence, through the Internet and through video games (Woodward \& Gridina, 2000). An American survey of over 1500 10- to 15 -year-olds found that $38 \%$ of adolescents had been exposed to violence on the Internet (Ybarra et al., 2008). The analysis of video games conducted by the USA Entertainment Software Rating Board research revealed that $90 \%$ of all games rated for children 10 years or older contain violence (Gentile, 2008).

The amount of exposure to media presents an important risk factor for children's behavior 
since the effects of media are subtle and cumulative over time (Prot \& Gentile, 2014). Most of the studies revealed that children on average watch TV around three hours per day (AEM/ UNICEF, 2014; Bilić, 2010; Brug et al., 2012), and some even show that children spent more time watching television than being in school (Marini, Dane, \& Bosacki, 2006). Time spent in playing video games adds to children and youth daily screen time since almost half of youth play it every day around 1 to 3 hours (Bilić, 2010; Lenhart et al., 2008; Verloigne et al., 2015). In addition, almost all adolescents (97\%), and somewhat fewer children, use the Internet (UCLA Internet Report, 2003). Half of children and adolescents who use the Internet use it every day both in USA (Lenhart, Madden, \& Hitlin, 2005), and in Croatia (Hrabri telefon i Poliklinika za zaštitu djece grada Zagreba, 2008). To sum it all up, the average American child, between the age of 8 and 18 years, spends 6 hours and 21 minutes every day using some kind of entertainment media (Roberts, Foehr, \& Rideut, 2005), and that is the longest time period that a child spends in any activity, except sleeping (Roberts, 2000). Similar duration of TV and video games use was found among the youth in European countries as well (Verloigne et al., 2015).

Many studies have shown that exposure to media violence is a significant risk factor for aggressive thoughts, emotions, attitudes and behavior in youth viewers and users (Potter $\&$ Riddle, 2007). It was found that exposure to violent content on television, video games and the Internet increases the likelihood of aggressive and violent behavior among children and adolescents (Anderson et al., 2004; Bushman \& Huesmann, 2006). Although experimental studies have found causal relationship between violence in media and aggressive behavior, the exposure to media is neither a necessary nor sufficient cause of youth's aggression (Bushman \& Anderson, 2015). The media effects that have been found are larger for milder forms of aggression $(d=0.39)$ than for criminal behavior $(d=0.20)$ (Bushman et al., 2016). Concerning duration of effects, both immediate and long lasting effects of media violence have been found. As for immediate and short term effects, media violence have been found to produce physiological arousal, priming of aggressive cognitions and scripts and triggering of an automatic imitation of aggressive behaviors (Berkowitz, 1993; Bjorkquist, 1985; Bushman \& Huesmann, 2001; Green, 1975). Longitudinal studies have found that heavy exposure to media violence in childhood is associated with physical, verbal and relational aggression during adulthood (Huesmann, Moise-Titus, Podolski, \& Eron, 2003; Lefkowitz, Eron, Walder, \& Huesmann, 1977). Violence portrayed in TV shows and films has been studied most extensively (Paik \& Comstock, 1994), but the violent media effect on children's and youth behavior was found also for the violence in video games (Anderson et al., 2010; Ferguson \& Kilburn, 2009). Furthermore, longitudinal data show that video games violence is related more to the increase in physical aggression in school children over time, while TV and movie violence is more related to the increase in verbal aggression (Anderson, Gentile, \& Buckley, 2007).

Using the Internet, children and adolescents can be exposed to inappropriate content, particularly through film clips, video games, music videos and other audiovisual formats. Research on the effects of aggressive music lyrics and music videos have found short-term effects on the increase of aggressive emotions and aggressive thoughts, as well as antagonism toward women and acceptability of violence in both oneself and the others (Roberts, Christenson \& Gentile, 2003). In addition, children on the Internet interact through social media, chat rooms, blogs and messengers, which can all be ways through which they can be ex- 
posed to violence and inflict violence on others (Williams \& Guerra, 2007).

Youths' exposure to media is considered one of the most important exosystem's risk factor for bullying and other sorts of violence toward peers (Hong \& Espelage, 2012). Zimmerman, Glew, Christakis, and Katon (2005) found that the number of hours of television viewed per day at age 4 was associated with being nominated as a bully at ages 6 through 11 years. Kuntsche (2004) found the association between television viewing and bullying and feeling unsafe at school. Analyzing data for over 30,000 adolescents aged 11,13 and 15 years from eight American and European countries Kuntsche et al. (2006) found bivariate correlations between frequency of television viewing and different verbal bullying behaviors (name calling, spreading rumors), as well as physical bullying (kicking and pushing) in most of the countries. Dittrick et al. (2013) found the media effects of playing violent video games on both traditional bullying and cyberbullying.

Theoretical models that explain the psychological processes underlying violent media effects are numerous, but most of them fall under information processing and social-cognitive models (Anderson, 2004). Some of the processes involved contribution to short-term effects (spreading neural activation, priming, mimicry), while others contribute to long-term effects of media violence on youth and humans generally (observational learning, automatization of aggressive schematic processing, and desensitization to violence) (Anderson, 2004; Federman, 1997; Gentile, Lynch, Linder, \& Walsh, 2004; Krahé et al., 2012). Interactive media, such as video games and the Internet, seem to have even greater potential to affect children's and adolescents' behavior negatively than more passive media as television (Anderson, Gentile, \& Buckley, 2007). Violent video games require from players to identify with the violent character represented in the game and to get actively involved in the violence (Carll, 2003; Turkle, 2002). Playing violent video games was found to increase children's aggressive behavior such as fights and arguments with teachers, knowledge about violence, aggressive emotions and psychological arousal while decreasing prosocial behavior (Anderson, 2004; Barboza et al., 2009; Gentile \& Walsh, 2002).

Studies have found that media violence does not affect all children and adolescents to the same degree, and that certain characteristics of viewers, media content and social environment moderate that effect (Anderson et al., 2004). The Differential Susceptibility to Media Effects Model (DSSM - Valkenburg \& Peter, 2013) conceptualizes three broad types of conditional variables under which media effects are more or less present. They are developmental, dispositional and social susceptibility variables that exist before media use situation and act both as predictors of media use, and as moderators of the effects of media use. Some research indicates greater susceptibility to violent media of younger children (Paik \& Comstock, 1994) while some others found larger effects for young adults than for adolescents (Johnson et al., 2002). Similarly inconclusive is research on the moderation of the child's gender since some found stronger violence media effects on male than female users (Paik \& Comstock, 1994), while others reported similar effects for both genders (Huesmann et al., 2003). The authors of DSSM model postulate that social contexts can also encourage or discourage media use as well as amplify or diminish media effects. Social influences occur through the influence of parents, siblings, peers, schools or institutions that regulate media use, and communicate norms about violence (Jordan, 2004; McDonald, 2009). Studies of factors that mediate between media usage and aggressive behavior among children revealed that one of the most important factors of the impact of media is parental involvement 
in the different forms of communication and supervision (Anderson, 2004; Eisenberg, Damon, \& Lerner, 2006). Parental limitation of children's time of playing computer games was shown to reduce aggressive behavior among children (Gentile et al., 2004). Nathanson and Cantor (2000) identified parental active mediation (talking with adolescents and children about the media and its contents) as well as parental restrictive mediation (setting up rules and regulations about media use). It was shown that active mediation is more effective in lessening the impact of media violence than restrictive strategies (Nathanson \& Yang, 2003) and that parental monitoring of children's media use has protective effects on children's sleep, school performance and aggressive behavior (Gentile, Reimer, Nathanson, Walsh, \& Eisenmann, 2014). Besides, parents have an important role in their children's peer-violence. Lack of parental involvement and support were found to be associated with bullying perpetration (Barboza et al., 2009; Holt \& Espelage, 2007), while parental maltreatment was found to be a risk factor for bullying victimization (Shield \& Cicchetti, 2001). In one study in Croatia the moderator effects of parental supervision, punishment and parental visits to school were found to influence the relationship between perception of neighborhood danger, impulsivity, and peer violence (Velki, 2012). Parental supervision and parental visits to school moderate the correlation between impulsivity and peer violence. However, in case of greater parental supervision, weakness in correlation between impulsivity and peer violence was found, but the results were contrary for parental visits to school; more visits to school increased the correlation between impulsivity and peer violence. Also, parental punishment moderates the correlation between students' perception of neighborhood danger and peer violence, whereas in case of greater parental punishment, an increase in correla- tion between students' perception of neighborhood danger and peer violence was found.

Peers are important socializing agents during adolescence and can moderate the effects of media as well as violent behaviors. Fikkers, Piotrowski, Lugtig, and Valkenburg (2016) found among 10 to 14 year-olds that media violence increased aggressive behavior among adolescents who perceived more peer aggression, but decreased aggression among those adolescents who perceived less peer aggression. A number of researchers found that peers play a significant role in bullying perpetration and victimization (e.g., Barboza et al., 2009; Schmidt \& Bagwell, 2007).

While the importance of peers and parents are recognized for both aggressive adolescents' behaviors as well as for their media use, the research that examines the effects of various types of media on different forms of violence among the same children is still limited (Bilić, 2010; Dittrick et al., 2013). In addition, while the mediating and moderating role of parents and peers on the negative effects of media were examined, the specific interaction between media and social-context effects has received little attention (Valkenburg \& Peter, 2013). Finally, the research of the effects of media use on violence towards peers has been predominantly conducted in USA, Japan and in larger European countries, but these effects are much less investigated in countries that have passed through war and change of economic policy like Croatia. Namely, in post-war society violence may be more often present in the media, and it may also be considered as more a acceptable behavior than in societies that have not seen war for a long time. In addition, Croatia has been going through transition from socialistic central planning to a free market economy and that caused changes in the value system from more collectivistic to individualistic and materialistic values. The transition was non-transparent and often crimi- 
nal and has been often depicted in media. Also, the increase of violent and other commercial content increased as new private media sprung up after decades of exclusively state regulated media.

The purpose of the current study was to address the inconsistencies and limitations in prior literature and to investigate which social contexts moderate the violent media effect and how. Therefore, the present study had three aims. First, to examine the amount of time that children use three different media (TV, Internet and video games) as well as the social context in which children use them (peers, parents, alone). Second, to investigate the relationship between times spent in different media use and different types of peer aggression (verbal, physical and electronic) and to test, if there are age and gender differences in that relationships. Finally, the third aim was to examine a potential moderator role of social context in which children are exposed to media (alone, with peers, with parents) on the relationship between the frequency of media use and the frequency of committed various types of peer aggression. The aim was also to explore whether potential moderator role applies to the three types of media. It was hypothesized: a) that adolescents use TV more in the company of parents, play video games more in the company of peers while they use internet more often alone and with peers than with parents, b) that the relationship between time spent with media and different forms of peer aggression will be positive in cases of all media but stronger for boys and for younger children, c) that the parental social context weakens the connection between the frequency of media usage and the aggression towards peers while presence of the peers can either strengthen or reduce media effect on peer aggression, d) the more often adolescents use certain media in certain social context, the social context has more potential to moderate that media effect on peer aggression.

\section{Method}

\section{Participants}

The participants were students of $5^{\text {th }}$ to $8^{\text {th }}$ grades from six elementary schools in Eastern Croatia. A total number was 880 participants (52\% girls). The average age of students was $M=12.8(S D=1.15)$ years, and the age ranged from $10-15$ years.

\section{Instruments}

Peer Violence among School Children Questionnaire (UNŠD; Velki \& Kuterovac Jagodić, 2012). This instrument was designed for selfassessment of peer violence and victimization, and consists of two scales. The scale of peer violence among children measures the frequency of violence committed against peers at school, and the scale of peer victimization measures the frequency of experienced violence at school. Both of the scales consist of 19 items. The scale of peer violence among children consists of Subscale of violence among children in schools [13 items divided into Subscale of verbal violence (6 items) and Subscale of physical violence (7 items)] and Subscale of electronic violence ( 6 items). The scale of peer victimization also consists of two subscales: Subscale victimization in schools [13 items divided into Verbal victimization subscale (6 items) and Subscales of physical victimization (7 items)] and Subscale of electronic victimization (6 items). Children indicate the frequency of each experienced/committed form of violence on a 5-point Likert scale where 1 means "never", 2 "rare (a few times per year)", 3 "sometimes (once a month)", 4 "frequently (several times per month)", and 5 "always (nearly every day)". The result for each subscale is computed as arithmetic mean of responses to the corresponding items, and theoretically ranges from 1 to 5 . 
The internal consistency for the scale of peer violence among children and its subscales was $\alpha=.66$ to .83 , and for the scale of peer victimization and its subscales from $\alpha=.70$ to .87 . For the purpose of this study we used only results from the Subscale of violence among children in schools that measures commitment of peer violence.

Exposure to the Media Scale (UM; Velki \& Kuterovac Jagodić, 2012). This self-report scale consists of three items related to the amount of time children spend with media (watching TV daily, playing computer games and browsing the Internet weekly). The exposure to violence in media was estimated from the possibility of exposure while watching different programs, browsing the Internet or playing video games (Slater, 2004). There are five time ranges offered that ranged from 1 to 5 , where 1 indicates that the participant does not use a particular media, 2 means the use of less than 3 hours per day/week, 3 means 3 to 5 hours per day/week, 4 means 6 to 10 hours per day/week and 5 means a maximum time of its use (more than 10 hours per day watching television and more than 10 hours per week for Internet and computer games). The total score is obtained as arithmetic mean of answers on all the items and can theoretically range from 1 to 5 . The internal consistency of the scale was satisfactory but low, $\alpha=.66$. For each of the media participants were asked to mark the social context in which they most commonly use specific media (mostly alone, with an adult or peer/siblings). For the purpose of the analyses in this study, the data on frequency of use was collapsed in two categories: up to 5 hours per day/week and more than 5 hours per day/week.

\section{Procedure}

The data was collected as a part of a larger study that tested ecological model of peer vio- lence and examined several factors in micro-, meso- and exsosystems of a child's environment (Velki, 2012). With the permission of the responsible national educational institutions and written parental consent and the consent of the children, data were collected collectively during classes in schools. Before the data collection the students were clearly reminded of the possibility to give up at any time and guaranteed confidentiality of the data obtained in the study. First, students filled out Peer Violence among School Children Questionnaire and then Exposure to the Media Scale. Upon completion of the questionnaires the students were offered the possibility to talk about the problem of peer violence and other problems with the school psychologist and the researcher, and they also got the contact e-mail and telephone number for further follow-up questions.

\section{Results}

\section{Time and Social Context of Media Use}

Table 1 presents the basic descriptives for the measured variables. The data reveal that the adolescents spent significant amount of time using different media. While the majority of adolescents report watching TV up to 5 hours per day $(89.9 \%)$ and playing video games up to five hours per week $(69.2 \%)$, they are more evenly divided in the use of the Internet in both categories $(57 \%$ vs. $43 \%$ ). As for the social context, TV was most often watched in the company of parents $(52.5 \%)$, then with peers $(31.3 \%)$ and the least often alone $(16.2 \%)$. The situation was opposite for video games and the Internet, which were used most often without any supervision (52.9\% video games, $59.3 \%$ the Internet), and in second place in the company of peers $(38.8 \%$ video games, $27.7 \%$ the Internet). 
Table 1 Frequency of the social context and time children spent watching TV, browsing the Internet and playing video games

\begin{tabular}{|c|c|c|c|c|c|c|c|c|c|c|}
\hline & \multicolumn{4}{|c|}{ Frequency of use } & \multicolumn{6}{|c|}{ Social context of media use } \\
\hline & \multicolumn{2}{|c|}{ up to $5 \mathrm{~h}$} & \multicolumn{2}{|c|}{ more than $5 \mathrm{~h}$} & \multicolumn{2}{|c|}{ Alone } & \multicolumn{2}{|c|}{ Peers } & \multicolumn{2}{|c|}{ Parents } \\
\hline & $\mathrm{N}$ & $\%$ & $\mathrm{~N}$ & $\%$ & $\mathrm{~N}$ & $\%$ & $\mathrm{~N}$ & $\%$ & $\mathrm{~N}$ & $\%$ \\
\hline TV (daily) & 785 & 89.9 & 88 & 10.1 & 141 & 16.2 & 273 & 31.3 & 456 & 52.5 \\
\hline $\begin{array}{l}\text { Video games } \\
\text { (weekly) }\end{array}$ & 604 & 69.2 & 269 & 30.8 & 447 & 52.9 & 328 & 38.8 & 70 & 8.3 \\
\hline $\begin{array}{l}\text { The Internet } \\
\text { (weekly) }\end{array}$ & 497 & 57 & 376 & 43 & 511 & 59.3 & 239 & 27.7 & 112 & 13 \\
\hline
\end{tabular}

Table 2 Correlation between time spent using media and peer aggression $(N=880)^{1}$

\begin{tabular}{lcccc}
\hline & $\begin{array}{c}\text { Overall peer } \\
\text { aggression }\end{array}$ & $\begin{array}{c}\text { Verbal peer } \\
\text { aggression }\end{array}$ & $\begin{array}{c}\text { Physical peer } \\
\text { aggression }\end{array}$ & $\begin{array}{c}\text { Electronic peer } \\
\text { aggression }\end{array}$ \\
\hline $\begin{array}{l}\text { Time spent browsing the } \\
\text { Internet }\end{array}$ & $.235^{* *}$ & $.193^{* *}$ & $.236^{* *}$ & $.132^{* *}$ \\
$\begin{array}{l}\text { Time spent playing video } \\
\text { games }\end{array}$ & $.208^{* *}$ & $.154^{* *}$ & $.241^{* *}$ & $.095^{* *}$ \\
Time spent watching TV & $.178^{* *}$ & $.173^{* *}$ & $.131^{* *}$ & $.126^{* *}$ \\
\hline $\begin{array}{l}\text { Note. } \\
\text { time } \text { There were no statistical significant gender and age differences in correlation between }\end{array}$ \\
$* * \mathrm{p}<0.01 ; * \mathrm{p}<0.05$
\end{tabular}

Testing for the Relationship between Media Exposure and Peer Aggression Relating to Age and Gender Differences

In order to test the hypothesis of the effect of media on aggressive behavior of adolescents, Pearson's correlations between frequency of watching television, playing video games and browsing the Internet and frequency of different types of peer aggressive perpetration (physical, verbal and electronic), as well as total peer aggression were calculated. The correlations between time spent in using different media and all types of peer aggression (Table 2) are positive, significant and fairly comparable to the effects typically obtained by media violence researchers (e.g., Anderson et al., 2010). Fisher's z-test was used to compare correlations for different types of aggression and for different media. Media effects of time using the Internet were similarly strong for all types of aggression toward peers. Media effects of video games were similarly strong for physical and verbal aggression, and less strong for the electronic peer aggression in comparison to physical aggression $(z=3.15$, $p=.001)$. Finally, media effect of TV was equally strong for all kinds of peer aggression. Although correlations for overall peer aggression were not significantly different for different media, the separate analyses revealed that effects of all media are similar for verbal peer aggression and for electronic peer aggres- 
sion, while for physical aggression the negative effects of the time spent using Internet and playing video games are stronger than the effect of time spent watching television $(z=$ $2.28, p=.02 ; z=2.38, p=.012)$. There were no significant age (older vs. younger students) and gender (male vs. female students) differ- ences in any of the two correlations between time spent using media and self-reported frequency of perpetrating aggression towards peers (Fisher's z-test showed there were no statistical significant differences between any two correlation coefficients calculated separately for the age and gender subgroups).

Table 3 Multiple regression analyses of time and social context of TV watching on different forms of peer aggression

\begin{tabular}{|c|c|c|c|}
\hline Dependent variables & $\begin{array}{l}\text { Verbal peer } \\
\text { aggression }\end{array}$ & $\begin{array}{c}\text { Physical peer } \\
\text { aggression }\end{array}$ & $\begin{array}{c}\text { Electronic peer } \\
\text { aggression }\end{array}$ \\
\hline Predictors & $\beta$ & $\beta$ & $\beta$ \\
\hline Time spent watching TV & $.173^{* *}$ & $.131^{* *}$ & $.126^{* *}$ \\
\hline Regression model 1 & $\begin{array}{c}\mathrm{R}=0.173 \\
\mathrm{R}^{2}=0.030 \\
\mathrm{R}^{2} \text { kor }=0.029 \\
\mathrm{~F}_{(1,870)}=26.90 \\
\mathrm{p}<0.001\end{array}$ & $\begin{array}{c}\mathrm{R}=0.131 \\
\mathrm{R}^{2}=0.017 \\
\mathrm{R}_{\text {kor }}^{2}=0.016 \\
\mathrm{~F}_{(1,870)}=15.29 \\
\mathrm{p}<0.001\end{array}$ & $\begin{array}{c}\mathrm{R}=0.126 \\
\mathrm{R}^{2}=0.016 \\
\mathrm{R}_{\text {kor }}^{2}=0.015 \\
\mathrm{~F}_{(1,870)}=13.98 \\
\mathrm{p}<0.001\end{array}$ \\
\hline Time spent watching TV & $.172 * *$ & $.130 * *$ & $.123^{* *}$ \\
\hline alone vs. peers & -.067 & -.070 & -.059 \\
\hline alone vs. parents & -.082 & -.068 & $-.138 * *$ \\
\hline Regression model 2 & $\begin{array}{c}\mathrm{R}=0.183 \\
\mathrm{R}^{2}=0.033 \\
\mathrm{R}_{\text {kor }}^{2}=0.030 \\
\mathrm{~F}_{(2,868)}=1.55 \\
\mathrm{p}>0.05\end{array}$ & $\begin{array}{c}\mathrm{R}=0.142 \\
\mathrm{R}^{2}=0.020 \\
\mathrm{R}_{\text {kor }}^{2}=0.017 \\
\mathrm{~F}_{(2,868)}=1.24 \\
\mathrm{p}>0.05\end{array}$ & $\begin{array}{c}\mathrm{R}=0.164 ; \\
\mathrm{R}^{2}=0.027 \\
\mathrm{R}_{\text {kor }}^{2}=0.023 \\
\mathrm{~F}_{(2,868)}=4.87 \\
\mathrm{p}<0.01\end{array}$ \\
\hline $\begin{array}{l}\text { Time spent watching TV } \\
\text { alone vs. peers } \\
\text { alone vs. parents } \\
\text { time TV x peers } \\
\text { time TV x parents }\end{array}$ & $\begin{array}{l}.235^{* *} \\
-.047 \\
.094 \\
-.020 \\
-.193 \\
\end{array}$ & $\begin{array}{l}.163 * * \\
.058 \\
-.051 \\
-.137 \\
-.018 \\
\end{array}$ & $\begin{array}{l}.305^{* *} \\
.199 \\
.238 \\
-.274 * \\
-.410^{* *} \\
\end{array}$ \\
\hline Regression model 3 & $\begin{array}{c}\mathrm{R}=0.191 \\
\mathrm{R}^{2}=0.037 \\
\mathrm{R}_{\text {kor }}^{2}=0.031 \\
\mathrm{~F}_{(2,866)}=1.44 \\
\mathrm{p}>0.05\end{array}$ & $\begin{array}{c}\mathrm{R}=0.147 \\
\mathrm{R}^{2}=0.022 \\
\mathrm{R}_{\text {kor }}^{2}=0.016 \\
\mathrm{~F}_{(2,866)}=0.69 \\
\mathrm{p}>0.05\end{array}$ & $\begin{array}{c}\mathrm{R}=0.191 ; \\
\mathrm{R}^{2}=0.036 \\
\mathrm{R}_{\text {kor }}^{2}=0.031 \\
\mathrm{~F}_{(2,866)}=4.36 \\
\mathrm{p}<0.05\end{array}$ \\
\hline
\end{tabular}

Note. $* * \mathrm{p}<0.01 ; * \mathrm{p}<0.05$

Results have shown significant difference between two moderation effects (colored gray in Table 3 ) of peers and parents whereas parents had significantly stronger moderation effects $\left(\mathrm{t}_{(1,676)}=4.18, \mathrm{p}<0.001\right)$. 


\section{Moderating Role of a Social Context in which Media are Used}

In accordance with the third aim, a potential moderator role of the social context in the relationship between time spent on different type of media and the level of perpetrating different types of aggressive behavior towards peers was examined. Separate regression analyses were performed in which time was treated as continuous variable and used to predict peer aggression scores, while social context variables were coded as dummy variables (alone vs. peers, alone vs. parents) and included in the models as moderators. The results of those regressions

Table 4 Multiple regression analyses of time and social context of video games playing on different forms of peer aggression

\begin{tabular}{|c|c|c|c|}
\hline Dependent variables & $\begin{array}{l}\text { Verbal peer } \\
\text { aggression }\end{array}$ & $\begin{array}{l}\text { Physical peer } \\
\text { aggression }\end{array}$ & $\begin{array}{l}\text { Electronic peer } \\
\text { aggression }\end{array}$ \\
\hline Predictors & $\beta$ & $\beta$ & $\beta$ \\
\hline $\begin{array}{l}\text { Time spent playing video } \\
\text { games }\end{array}$ & $.154 * *$ & $.241 * *$ & $.095 * *$ \\
\hline Regression model 1 & $\begin{array}{c}\mathrm{R}=0.154 \\
\mathrm{R}^{2}=0.024 \\
\mathrm{R}_{\text {kor }}^{2}=0.023 \\
\mathrm{~F}_{(1,870)}=21.24 \\
\mathrm{p}<0.001\end{array}$ & $\begin{array}{c}\mathrm{R}=0.241 ; \\
\mathrm{R}^{2}=0.058 \\
\mathrm{R}_{\text {kor }}^{2}=0.057 \\
\mathrm{~F}_{(1,870)}=53.51 \\
\mathrm{p}<0.001\end{array}$ & $\begin{array}{c}\mathrm{R}=0.095 \\
\mathrm{R}^{2}=0.009 \\
\mathrm{R}_{\text {kor }}^{2}=0.008 \\
\mathrm{~F}_{(1,870)}=7.97 \\
\mathrm{p}<0.01\end{array}$ \\
\hline $\begin{array}{l}\text { Time spent playing video } \\
\text { games }\end{array}$ & $.156 * *$ & $.242 * *$ & $.097 * *$ \\
\hline alone vs. peers & -.060 & $-.084 * *$ & -.002 \\
\hline alone vs. parents & -.032 & -.038 & -.032 \\
\hline Regression model 2 & $\begin{array}{c}\mathrm{R}=0.166 \\
\mathrm{R}^{2}=0.028 \\
\mathrm{R}_{\text {kor }}=0.024 \\
\mathrm{~F}_{(2,868)}=1.66 \\
\mathrm{p}>0.05\end{array}$ & $\begin{array}{c}\mathrm{R}=0.255 \\
\mathrm{R}^{2}=0.065 \\
\mathrm{R}_{\text {kor }}^{2}=0.062 \\
\mathrm{~F}_{(2,868)}=3.27 \\
\mathrm{p}<0.05\end{array}$ & $\begin{array}{c}\mathrm{R}=0.100 \\
\mathrm{R}^{2}=0.010 \\
\mathrm{R}_{\text {kor }}^{2}=0.007 \\
\mathrm{~F}_{(2,868)}=0.44 \\
\mathrm{p}>0.05\end{array}$ \\
\hline $\begin{array}{l}\text { Time spent playing video } \\
\text { games } \\
\text { alone vs. peers } \\
\text { alone vs. parents } \\
\text { games x peers } \\
\text { games x parents }\end{array}$ & $\begin{array}{l}.118 * * \\
-.141 \\
-.101 \\
.095 \\
.078 \\
\end{array}$ & $\begin{array}{c}.234^{* *} \\
-.115 \\
-.016 \\
.037 \\
-.024\end{array}$ & $\begin{array}{r}.064 \\
-.095 \\
-.029 \\
.109 \\
-.002\end{array}$ \\
\hline Regression model 3 & $\begin{array}{c}\mathrm{R}=0.172 ; \\
\mathrm{R}^{2}=0.030 \\
\mathrm{R}^{2}{ }_{\text {kor }}=0.024 \\
\mathrm{~F}_{(2,866)}=0.94 \\
\mathrm{p}>0.05\end{array}$ & $\begin{array}{c}\mathrm{R}=0.256 ; \\
\mathrm{R}^{2}=0.065 \\
\mathrm{R}^{2}{ }_{\text {kor }}=0.060 \\
\mathrm{~F}_{(2,866)}=0.18 \\
\mathrm{p}>0.05\end{array}$ & $\begin{array}{c}\mathrm{R}=0.111 ; \\
\mathrm{R}^{2}=0.012 \\
\mathrm{R}_{\text {kor }}^{2}=0.007 \\
\mathrm{~F}_{(2,866)}=0.94 \\
\mathrm{p}>0.05\end{array}$ \\
\hline
\end{tabular}

Note. $* * \mathrm{p}<0.01 ; * \mathrm{p}<0.05$ 
are summarized in Tables 3, 4 and 5. Main effects of time were supported for all the media and all kinds of peer aggression, i.e. the children who report spending more time using media also report committing more verbal, physical and electronic aggression towards their peers.
Parental social context significantly moderated three relations between the time of media use and peer aggression. In the case of TV watching and the use of the Internet, the social context of parents and peers was a significant moderator for electronic peer aggression. That means that the negative relationships between

Table 5 Multiple regression analyses of time and social context of the Internet browsing on different forms of peer aggression

\begin{tabular}{|c|c|c|c|}
\hline Dependent variables & $\begin{array}{l}\text { Verbal peer } \\
\text { aggression }\end{array}$ & $\begin{array}{l}\text { Physical peer } \\
\text { aggression }\end{array}$ & $\begin{array}{c}\text { Electronic peer } \\
\text { aggression }\end{array}$ \\
\hline Predictors & $\beta$ & $\beta$ & $\beta$ \\
\hline $\begin{array}{l}\text { Time spent browsing the } \\
\text { Internet }\end{array}$ & $.193 * *$ & $.236^{* *}$ & $.132 * *$ \\
\hline Regression model 1 & $\begin{array}{c}\mathrm{R}=0.193 \\
\mathrm{R}^{2}=0.037 \\
\mathrm{R}_{\text {kor }}^{2}=0.036 \\
\mathrm{~F}_{(1,870)}=33.82 \\
\mathrm{p}<0.001\end{array}$ & $\begin{array}{c}\mathrm{R}=0.236 ; \\
\mathrm{R}^{2}=0.056 \\
\mathrm{R}^{2} \text { kor }=0.055 \\
\mathrm{~F}_{(1,870)}=51.22 \\
\mathrm{p}<0.001\end{array}$ & $\begin{array}{c}\mathrm{R}=0.132 ; \\
\mathrm{R}^{2}=0.018 \\
\mathrm{R}_{\text {kor }}^{2}=0.016 \\
\mathrm{~F}_{(1,870)}=15.50 \\
\mathrm{p}<0.001\end{array}$ \\
\hline $\begin{array}{l}\text { Time spent browsing the } \\
\text { Internet }\end{array}$ & $.185^{* *}$ & $.224 * *$ & $.121^{* *}$ \\
\hline alone vs. peers & -.002 & $-.069 *$ & -.001 \\
\hline alone vs. parents & -.056 & $-.080 *$ & $-.075 *$ \\
\hline Regression model 2 & $\begin{array}{c}\mathrm{R}=0.201 \\
\mathrm{R}^{2}=0.040 \\
\mathrm{R}_{\text {kor }}^{2}=0.037 \\
\mathrm{~F}_{(2,868)}=1.36 \\
\mathrm{p}>0.05\end{array}$ & $\begin{array}{c}\mathrm{R}=0.253 \\
\mathrm{R}^{2}=0.064 \\
\mathrm{R}_{\text {kor }}^{2}=0.061 \\
\mathrm{~F}_{(2,868)}=3.93 \\
\mathrm{p}<0.05\end{array}$ & $\begin{array}{c}\mathrm{R}=0.151 ; \\
\mathrm{R}^{2}=0.023 \\
\mathrm{R}^{2}{ }_{\text {kor }}=0.020 \\
\mathrm{~F}_{(2,868)}=2.42 \\
\mathrm{p}>0.05\end{array}$ \\
\hline $\begin{array}{l}\text { Time spent browsing the } \\
\text { Internet } \\
\text { alone vs. peers } \\
\text { alone vs. parents } \\
\text { net } x \text { peers } \\
\text { net x parents }\end{array}$ & $\begin{array}{r}.023 \\
-.018 \\
-.027 \\
-.040 \\
\end{array}$ & $\begin{array}{l}-.016 \\
.001 \\
-.057 \\
-.084 \\
\end{array}$ & $\begin{array}{r}.054 \\
.056 \\
-.060 \\
-.138 \\
\end{array}$ \\
\hline Regression model 3 & $\begin{array}{c}\mathrm{R}=0.202 \\
\mathrm{R}^{2}=0.041 \\
\mathrm{R}_{\text {kor }}^{2}=0.035 \\
\mathrm{~F}_{(2,866)}=0.16 \\
\mathrm{p}>0.05\end{array}$ & $\begin{array}{c}\mathrm{R}=0.255 \\
\mathrm{R}^{2}=0.065 \\
\mathrm{R}_{\text {kor }}^{2}=0.060 \\
\mathrm{~F}_{(2,866)}=0.53 \\
\mathrm{p}>0.05\end{array}$ & $\begin{array}{c}\mathrm{R}=0.160 \\
\mathrm{R}^{2}=0.026 \\
\mathrm{R}^{2}{ }_{\text {kor }}=0.020 \\
\mathrm{~F}_{(2,866)}=1.20 \\
\mathrm{p}>0.05\end{array}$ \\
\hline
\end{tabular}


time spent watching TV and electronic aggression were less prominent for children whose parents or peers are usually present during their TV watching. Parental presence had stronger moderator effects than presence of their peers. Parental presence during children's browsing the Internet also decreased the physical and electronic aggression towards peers. Parental presence, however, did not moderate the relationship between frequency of time of any media use and verbal aggression. Peer social context moderated negative media effects only for TV and electronic aggression towards peers. But social context of peers had more direct influence. If children play video games or use the Internet with their peers, there is a decrease in their physical aggression towards peers. In addition, since adolescents watch TV mostly in the company of parents (Table 2) parents are moderators for some media effects of TV on peer aggression, but since they play video games mostly with peers, the peers have more direct effect on committing peer aggression. Finally, since adolescents use the Internet both in the company of parents and peers (Table 2) they both have influence on some forms of peer aggression.

To summarize, the negative effects of time of use of some media on some kinds of peer aggression depends on social context in which children consume those media.

\section{Discussion}

This study investigated the use of different media and social context of their use in Croatian adolescents, as well as the moderating roles of the social context of media use on the relationship between time of media use and aggression towards peers. Croatian adolescents spend significant amount of time using different media and most of them spend 5 or less hours per day watching TV, in most of the cases with their parents present. These results are in line with earlier studies which revealed that most children watch TV around three hours per day (Bilić, 2010; Verloigne et al., 2015) and with common knowledge that TV is most often family activity in the families with children. However, it is worth noting that around $10 \%$ of the adolescents watch TV more than 5 hours per day, which could represent a risk factor for their social and emotional development.

In addition most of the adolescents also reported spending up to 5 hours per week playing video games which corresponds to some European data according to which children play video games around 1.5 hours per day (Verloigne et al., 2015). Half of the adolescents reported to play video games alone, while more than one third of them reported usually playing with their peers. Some of the children (8\%) reported to play video games most often with their parents who in such way present strong role models for that activity. Around half of the children reported to use the Internet more than 5 hours per week. The adolescents reported that they use the Internet most often alone, following by the presence of other peers, while one tenth of the sample use it with parents. Use of the Internet and playing video games were mostly reported to be individual activities, following by the company of peers, but generally with the least parental supervision. Knowing that video games and the Internet could be packed with violence and inappropriate contents of all kinds, the use of those media without mediation could also be a risk factor for violent behavior.

Our research found evidence for violent media effect for three kinds of aggressive behavior towards peers (verbal, physical and electronic) and for all the media (TV, video games, the Internet). The more time the children spent watching $\mathrm{TV}$, playing video games or browsing the Internet the more they reported verbal, physical and electronic aggressive behaviors towards their peers. These results are in accor- 
dance with the previous research on peer violence (Bushman et al., 2016; Dittrick et al., 2013; Kuntsche, 2004; Zimmerman et al., 2005). Media violence effects were similar for both genders as well as for younger and older adolescents, which corresponds to some earlier studies (e.g., Huesmann et al., 2003; Valkenburg \& Cantor, 2000). Since the developmental level would be expected to predict media use and content preferences, it may be that our sample was not enough heterogeneous in age. The study found certain supporting evidence for the DSSM model (Valkenburg \& Peter, 2013), in which the social context plays an important role in media use creating certain social susceptibility or resistance to the effect of media violence. The mechanism of the effects of social context are postulated through deliberate efforts of parents, teachers and peers to regulate media use, as well as through more subtle messages, through norms and beliefs, they communicate to the adolescents about violent behavior in media (Jordan, 2004; McDonald, 2009).

As it was hypothesized, comparing to the adolescents' unaccompanied use of media, company of parents or peers may weaken the relationship of time spent with media and peer aggression. In the case of TV watching, the social contexts of parents and peers were significant moderators only for electronic peer aggression, i.e. the negative media effect of watching TV on electronic peer aggression is reduced if parents or peers were present during TV watching, while parents or peers were not moderators for other types of peer aggression. Parental supervision was a stronger moderator for the relationship between time spent in TV watching and electronic peer aggression. As earlier research in Croatia also found, viewing inappropriate content on television, especially if that took place in a social context without the supervision of adults, lowered the threshold of tolerance for violence (Ilišin, 2003; Wertag et al., 2006). Gentile et al. (2014) showed that increased parental monitoring reduced children's total screen time which in turn resulted in lower aggression behavior, better school performance and more sleep. During common TV time, parents can use active monitoring helping children to understand and interpret violent scenes and morally condemning them, and therefore diminishing negative effects of media violence. Namely, Nathanson (1999) for example, found that children who discussed inappropriateness of television violence with their parents had lower aggressive tendencies than those who did not.

Many research studies confirmed that playing violent computer games increases aggressive behavior, knowledge about aggression, aggressive emotions, and psychological arousal, and decreases prosocial behavior (Anderson, Gentile, \& Buckley, 2007; Barboza et al., 2009; Gentile \& Walsh, 2002). In our research we found such a relationship for playing video games generally, without specification of the kind of the games. Besides, we found that social context of peers while child is playing computer games, reduced physical peer aggression. That means that playing video games with peers decreased self-reported physical aggression towards peers, compared to situation in which video games were played alone. The results indicate that socializing with peers, especially if they are positive behavioral models to children, can contribute to the reduction of media related peer aggression (Fikkers et al., 2016).

Previous research also found a moderating role of social context for verbal peer violence, but not for physical violence towards peers (Anderson, Gentile, \& Buckley, 2007; Kuntsche, 2004), while we found that both parents and peers can serve as the regulators of negative effect of violent media (video games and the Internet) on self-reported physical aggression towards peers. The effect of the media on verbal aggression, on the other 
hand, was not moderated by either parent nor peer social context. It can be hypothesized that both parents and peers less often disapprove of verbal forms of aggression in media, as compared to physical aggression and that adolescents therefore more freely use such aggression against peers. In addition, it is interesting that the present research revealed a moderating role of parents in the relationship between quantities of TV watching and the adolescents' aggression carried out in another media, i.e. on the Internet, where electronic aggression takes place. It may be that adolescents who are heavy solo TV viewers learn violent behaviors and develop positive attitudes towards violence (Huesmann et al., 2003) as well as become desensitized towards it and then apply what they have learned in the electronic violence towards their peers (Huesmann, 2007). The fact that parental moderation of the Internet and TV effects is related to decrease in electronic aggression is a finding that needs more attention in future studies.

This research contributes to a vast amount of research findings on the media effects of violence by supporting the well-known relationships of media use and aggression, but also adds some additional light to the protective role of the social context of media use. In addition, this study contributes to the research on the risk factor of exposure to media for different kinds of aggression towards peers. Some of the shortcomings of this research were approximate measures of media violence and less precise measure of the social context. Also, all the data were self-reported by adolescents, which may increase relations among variables. However, although the exposure to media violence was not measured directly (we presumed that it would be difficult for children to assess quantity of the exposure to specific content), but through the total amount of time spent using particular media, the negative media effect was still revealed. That fact suggests a consistent effect and clearly demonstrates the importance of decreasing the adolescent's use of the media on the one hand, but also shows that the restriction of media time is not the only way to protect children from the effect of harmful contents in the media.

Similarly, the social context of co-viewing was measured by a single item (With whom of these do you consume the TV/video games/the Internet the most?). Perhaps it would have been better to assess the frequency of all social contexts separately for each media (e.g., How often do you play video games/watch TV/use Internet: a) with your parents, b) alone, c) with your friends?). This would likely yield more variability in this measure and may make it easier to find a significant interaction between media exposure and social context. However, certain moderating effects were found, in spite of the less optimal measures of the context, indicating that parental and peer presence can help adolescents resist the negative effects of media on aggressive behavior. It may be that, as postulated by McDonald (2009), during TV watching with parents, or game playing with peers, the "emotional contagion" between the co-viewers or co-players happens. Therefore, adolescents can synchronize with negative emotional responses, moods and expressed attitudes of parents or peers and in that way regulate their own excitative, emotional, cognitive, and behavioral reactions to media. This research also showed that the media effect does not know cultural borders and that Croatian adolescents often use different electronic media and react similarly to their peers all around the world. Future research should investigate the mechanisms by which not only parents, but peers of different characteristics and different level of similarity with media user, can moderate the negative effects of media on aggressive behavior towards peers and other types of violent behavior. 


\section{References}

AEM/UNICEF CROATIA (2014). Kako djeca gledaju TV program? IPSOS Media CT. http://www.unicef.hr/ sto-radimo/istrazivanja/

Anderson, C. A. (2004). An update on the effects of violent video games. Journal of Adolescence, 27, 113-122.

Anderson, C. A., Carnagey, N. L., Flanagan, M., Benjamin, A. J., Eubanks, J., \& Valentine, J. C. (2004). Violent video games: Specific effects of violent content on aggressive thoughts and behavior. Advances in Experimental Social Psychology, 36, 199-249.

Anderson, C. A., Gentile, D. A., \& Buckley, K. E. (2007). Violent video game effects on children and adolescents: Theory, research, and public policy. Oxford University Press.

Anderson, C. A., Shibuya, A., Ihori, N., Swing, E. L., Bushman, B. J., Sakamoto, A., \& Saleem, M. (2010). Violent video game effects on aggression, empathy, and prosocial behavior in Eastern and Western countries: A meta-analytic review. Psychological Bulletin, 136(2), 151-173.

Barboza, G. E., Schiamberg, L. B., Oehmke, J., Korzeniewski, S. J., Post, L. A., \& Heraux, C. G. (2009). Individual characteristics and the multiple contexts of adolescent bullying: An ecological perspective. Journal of Youth and Adolescence, 38(1), 101-121.

Bilić, V. (2010). The relation between media violence and aggressive peer behaviour. Odgojne znanosti, 12(20), 263-281.

Brug, J., van Stralen, M. M., te Velde, S. J., Chinapaw, M. J., De Bourdeaudhuij, I., Lien, N., \& Moreno, L. (2012). Differences in weight status and energy-balance related behaviors among school children across Europe: The ENERGY-project. PloS One, 7(4).

Bushman, B. J., \& Anderson, C. A. (2015). Understanding causality in the effects of media violence. American Behavioral Scientist, 59(14), 1807-1821.

Bushman, B. J., Newman, K., Calvert, S. L., Downey, G., Dredze, M., Gottfredson, M., \& Romer, D. (2016). Youth violence: What we know and what we need to know. American Psychologist, 71(1), 17 39.

Bushman, B. J. \& Huesmann, L. R. (2006). Short-term and long-term effects of violent media on aggression in children and adults. Archives of Pediatrics \& Adolescent Medicine, 160, 348-352.

Carll, E. K. (Ed.). (2003). Psychology, news media, and public policy: Promoting social change. American Behavioral Scientist, 46(12), 1591-1593.
Dittrick, C. J., Beran, T. N., Mishna, F., Hetherington, R., \& Shariff, S. (2013). Do children who bully their peers also play violent video games? A Canadian national study. Journal of School Violence, 12(4), 297-318.

Eisenberg, N., Damon, W., \& Lerner, R. M. (2006). Handbook of child psychology: Social, emotional, and personality development. New Jersey: John Wiley \& Sons, Inc.

Federman, J. (Ed.). (1997). National Television Violence study: Vol. 2. Executive Summary. Santa Barbara: University of California, Center for Communication \& Social Policy.

Ferguson, C. J., \& Kilburn, J. (2009). The public health risks of media violence: A meta-analytic review. Journal of Pediatrics, 154, 759-763.

Fikkers, K. M., Piotrowski, J. T., Lugtig, P., \& Valkenburg, P. M. (2016). The role of perceived peer norms in the relationship between media violence exposure and adolescents' aggression. Media Psychology, 19(1), 4-26.

Gentile, D. A. (2008). The rating systems for media products. The handbook of children, media, and development, 527-551.

Gentile, D. A., Lynch, P. J., Linder, J. R., \& Walsh, D. A. (2004). The effects of violent video game habits on adolescent aggressive attitudes and behaviors. Journal of Adolescence, 27, 5-22.

Gentile, D. A., Reimer, R. A., Nathanson, A. I., Walsh, D. A., \& Eisenmann, J. C. (2014). Protective effects of parental monitoring of children's media use: A prospective study. JAMA Pediatrics, 168(5), 479484 .

Gentile, D. A. \& Walsh, D. A. (2002). A normative study of family media habits. Journal of Applied Psychology, 23, 157-178.

Holt, M. K., \& Espelage, D. L. (2007). Perceived social support among bullies, victims, and bullyvictims. Journal of Youth and Adolescence, 36(8), 984-994.

Hong, J. S., \& Espelage, D. L. (2012). A review of research on bullying and peer victimization in school: An ecological system analysis. Aggression and Violent Behavior, 17(4), 311-322.

Hrabri telefon i Poliklinika za zaštitu djece grada Zagreba (2008). Nasilje preko interneta - cyberbullying. http://www.poliklinika-djeca.hr/publikacije/ nasilje-preko-interneta/

Huesmann, L. R. (2007). The impact of electronic media violence: Scientific theory and research. Journal of Adolescent Health, 41(6), S6-S13.

Huesmann, L. R., Moise-Titus, J., Podolski, C. L., \& Eron, L. D. (2003). Longitudinal relations between children's exposure to TV violence and their aggressive and violent behavior in young adulthood: 
1977-1992. Developmental Psychology, 39(2), 201221.

Huston, A. C., Donnerstein, E., Fairchild, H., Feshbach, N. D., Katz, P. A., Murray, J. P., \& Zuckerman, D. (1992). Big world, small screen. University of Nebraska.

Ilišin, V. (2003). Mediji u slobodnom vremenu djece i komunikacija o medijskim sadržajima. Medijska Istraživanja, 9(2), 9-34.

Johnson, J. G., Cohen, P., Smailes, E. M., Kasen, S., \& Brook, J. S. (2002). Television viewing and aggressive behavior during adolescence and adulthood. Science, 295, 2468-2471.

Jordan, A. (2004). The role of media in children's development: An ecological perspective. Journal of Developmental and Behavioral Pediatrics, 25(3), 196-206.

Krahé, B., Berkowitz, L., Brockmyer, J. H., Bushman, B. J., Coyne, S. M., Dill, K. E., \& Möller, I. (2012). Report of the media violence commission. Aggressive Behavior, 38(5), 335-341.

Kuntsche, E. N. (2004). Hostility among adolescents in Switzerland? Multivariate relations between excessive media use and forms of violence. Journal of Adolescent Health, 34(3), 230-236.

Kuntsche, E., Pickett, W., Overpeck, M., Craig, W., Boyce, W., \& de Matos, M. G. (2006). Television viewing and forms of bullying among adolescents from eight countries. Journal of Adolescent Health, 39(6), 908-915.

Lefkowitz, M. M., Eron, L. D., Walder, L. O., \& Huesmann, L. R. (1977). Growing up to be violent: A longitudinal study of the development of aggression. New York: Pergamon Press.

Lenhart, A., Kahne, J., Middaugh, E., Rankin Macgill, A., Evans, C., \& Vitak, J. (2008). Teens, video games, and civics: Teens' gaming experiences are diverse and include significant social interaction and civic engagement. Washington, DC: Pew Internet \& American Life Project.

Lenhart, A., Madden, M., \& Hitlin, P. (2005). Teens and technology: Youth are leading the transition to a fully wired and mobile nation. Washington, DC: Pew Internet \& American Life Project.

Marini, Z. A., Dane, A. V., \& Bosacki, S. L. (2006). Direct and indirect bully-victims: Differential psychosocial risk factors associated with adolescents involved in bullying and victimization. Aggressive Behavior, 32, 551-569.

McDonald, D. G. (2009). Media use and the social environment. In R. L. Nabi \& M. B. Oliwer (Eds) Media processes and effects (pp. 251-268). Los Angeles, CA: Sage.

Nathanson, A. I. (1999). Identifying and explaining the relationship between parental mediation and children's aggression. Communication Research, 26(2), 124-143.

Nathanson, A. I., \& Cantor, J. (2000). Reducing the aggression-promoting effect of violent cartoons by increasing children's fictional involvement with the victim: A study of active mediation. Journal of Broadcasting \& Electronic Media, 44(1), 125-142.

Nathanson, A. I., \& Yang, M. S. (2003). The effects of mediation content and form on children's responses to violent television. Human Communication Research, 29(1), 111-134.

Paik, H., \& Comstock, G. (1994). The effects of television violence on antisocial behavior: A meta-analysis. Communication Research, 21(4), 516-546.

Potter, W. J., \& Riddle, K. (2007). A content analysis of the media effects literature. Journalism \& Mass Communication Quarterly, 84(1), 90-104.

Prot, S., \& Gentile, D. (2014). Applying risk and resilience models to predicting the effects of media violence on development. Advances in Child Development and Behavior, 46, 215-244.

Roberts, D. F. (2000). Media and youth: Access, exposure, and privatization. Journal of Adolescence Health, 27, 8-14.

Roberts, D. F., Christenson, P. G., \& Gentile, D. A. (2003). The effects of violent music on children and adolescents. In D. A. Gentile (Ed.), Media violence and children: A complete guide for parents and professionals (pp.153-170).Westport, CT: Praeger.

Roberts, D. F., Foehr, U. G., \& Rideout, V. (2005). Generation M: Media in the lives of 8-18 year-olds. Menlo Park, CA: Kaiser Family Foundation.

Schmidt, M. E., \& Bagwell, C. L. (2007). The protective role of friendships in overtly and relationally victimized boys and girls. Merrill-Palmer Quarterly, 53(3), 439-460.

Shields, A., \& Cicchetti, D. (2001). Parental maltreatment and emotion dysregulation as risk factors for bullying and victimization in middle childhood. Journal of Clinical Child Psychology, 30(3), 349-363.

Turkle, S. (2002). E-Futures and E-Personae. In N. Leach (Ed.), Designing for a digital world (pp. 227255). London: John Wiley \& Sons.

UCLA Internet Report (2003). Surveying the digital future, year three. UCLA Center for Communication Policy. http://images.forbes.com/fdc/ mediaresourcecenter/UCLA03.pdf

Valkenburg, P. M., \& Cantor, J. (2000). Children's likes and dislikes of entertainment programs. Media Entertainment: The Psychology of its Appeal, 11, 135152.

Valkenburg, P. M., \& Peter, J. (2013). The differential susceptibility to media effects model. Journal of Communication, 63(2), 221-243. 
Velki, T. (2012). Verifying the ecological model of peer violence behavior. Unpublished doctoral dissertation, University of Zagreb, Croatia.

Verloigne, M., Van Lippevelde, W., Bere, E., Manios, Y., Kovács, É., Grillenberger, M., \& De Bourdeaudhuij, I. (2015). Individual and family environmental correlates of television and computer time in 10-to 12-year-old European children: The ENERGY-project. BMC Public Health, 15(1), 1 .

Wertag, A., Šakić, I., Boban, M., \& Bakić-Tomić, Lj. (2006). Frequency and characteristics of violence on Croatian national television. In Lj. Bakić-Tomić, V. Šimović, \& G. E. Lasker (Eds.), Pre-conference proceedings of the Special Fokus Symposium on 1st CISKS: Communication and Information Sciences in the Knowledge Society (pp.102-108). Zagreb: Europski centar za napredna i sustavna istraživanja.

Williams, K. R., \& Guerra, N. G. (2007). Prevalence and predictors of internet bullying. Journal of Adolescent Health, 41(6), S14-S21.
Wilson, B. J. (2008). Media and children's aggression, fear and altruism. The Future of Children, 18(1), 87118 .

Wilson, B., Smith, S., Potter, W. J., Kunkel, D., Linz, D., Colvin, C., \& Donnerstein, E. (2002). Violence in children's television programming: Assessing the risks. Journal of Communication, 52(1), 5-34.

Woodward, E. H. \& Gridina, N. (2000). Media in the home in 2000: The fifth annual survey of parents and children. Philadelphia: Annenberg Public Policy Center, University of Pennsylvania.

Ybarra, M. L., Diener-West, M., Markow, D., Leaf, P. J., Hamburger, M., \& Boxer, P. (2008). Linkages between internet and other media violence with seriously violent behavior by youth. Pediatrics, 122(5), 929-937.

Zimmerman, F. J., Glew, G. M., Christakis, D. A., \& Katon, W. (2005). Early cognitive stimulation, emotional support, and television watching as predictors of subsequent bullying among grade-school children. Archives of Pediatrics \& Adolescent Medicine, 159(4), 384-388. 